\title{
EFFECT OF DIETARY FISH MEAL REPLACEMENT BY POULTRY BY-PRODUCT MEAL ON MUSCLE FATTY ACID COMPOSITION AND LIVER HISTOLOGY OF FRY OF NILE TI- LAPIA, OREOCHROMIS NILOTICUS (ACTINOPTERYGII: PERCIFORMES: CICHLIDAE)
}

\author{
Baki AYDIN, Erkan GÜMÜŞ*, and Beytullah A. BALCI \\ Faculty of Fisheries, Akdeniz University, Antalya, Turkey
}

\begin{abstract}
Aydın B., Gümüş E., Balcı B.A. 2015. Effect of dietary fish meal replacement by poultry by-product meal on muscle fatty acid composition and liver histology of fry of Nile tilapia, Oreochromis niloticus (Actinopterygii: Perciformes: Cichlidae). Acta Ichthyol. Piscat. 45 (4): 343-351.
\end{abstract}

\begin{abstract}
Background. Poultry by-product meal (PBM) has been used as a potential substitute for fish meal (FM) in aquaculture feeds. However, there are concerns that high replacement of FM protein with PBM protein could adversely affect of the fish flesh quality, due to lowered ( $\Sigma$ n-3 PUFA) fatty acids content. While fatty acid composition of fish muscle has critical importance in human nutrition, the fish liver is a key organ that facilitates digestion of feed and plays an important role in fish digestive system. As has been recently demonstrated, the monitoring of this organ is important in FM replacement experiments. The aim of this study was to evaluate the potential use of PBM on the fatty acid composition of the muscles and on the histological structure of the liver of fry of Nile tilapia, Oreochromis niloticus (Linnaeus, 1758).

Materials and methods. Five isonitrogenous (34\%, crude protein), isolipidic (9\%, crude lipid), and isoenergetic (15 $\mathrm{MJ} \cdot \mathrm{kg}^{-1}$, digestible energy) diets were formulated to contain graded levels of PBM, where FM protein was replaced with PBM protein at $0 \%, 25 \%, 50 \%, 75 \%$, and $100 \%$ level with lysine-, methionine-, and threonine supplementation. Triplicate groups of 20 fish (mean weight $0.879 \mathrm{~g}$ ) were fed three times daily to apparent satiation for 12 weeks.

Results. At the end of the experiment, the fatty acid contents of the fish muscle were significantly affected by the experimental diets. As the FM content decreased, there was no reduction of saturated fatty acids; the diet with lowest FM protein percentage having the highest monounsaturated fatty acids and lowest polyunsaturated fatty acids (PUFA) proportions. The replacement of FM by PBM had a profound impact on the fatty acid composition of tilapia muscle with an increase in $\Sigma$ n-6 PUFA and a decrease in the $\Sigma$ n- 3 and $\Sigma$ n-3: $\Sigma$ n-6 PUFA ratio. The histological examination of liver tissue in all treatments of this study, revealed no histological abnormalities.

Conclusion. The replacement of FM with PBM (range 0\%-100\%) significantly decreases the amount of docosahexaenoic acid $(12.2 \%-1.2 \%)$ and eicosapentaenoic acid $(4.4 \%-0.4 \%)$ in the muscle of fish. Therefore, further study is needed with PBM as a substitute of FM to determine acceptable fatty acid composition for commercial production.
\end{abstract}

Keywords: practical diet, fishmeal substitution, alternative protein, feeding, liver, muscle

\section{INTRODUCTION}

Fish meal (FM), the major ingredient of fish feed, is commonly used fish diets in the rate of $20 \%-60 \%$ (Watanabe 2002). The availability of FM, however, cannot be guaranteed any longer because the capture fisheries are levelling off (Hlophe and Moyo 2014). Hence, partial or total replacement of FM with cost-effective, widely available, plant or animal protein sources has been important for developing aquaculture sector (Yang et al. 2006, Hernández et al. 2014). Poultry by-product meal (PBM) is one of these alternative protein sources and has long been evaluated as a potential substitute for FM in aquaculture feeds (Aydın and Gümüş 2013). Encouraging results for the utilization of PBM protein to replace FM protein in aquaculture feeds have been reported for species such as mirror carp, Cyprinus carpio Linnaeus, 1758 (see Emre et al. 2003); black sea turbot, Scophthalmus maeoticus (Pallas, 1814) (see Turker et al. 2005); Prussian carp, Carassius auratus gibelio (Bloch, 1782) (see Yang et al. 2006); Malaysian mahseer, Tor tambroides (Bleeker, 1854) (see Ismail et al. 2012); Nile tilapia, Oreochromis niloticus (Linnaeus, 1758) (see Hernández et al. 2010, Aydin and Gümüş 2013); and rainbow trout, Oncorhynchus mykiss (Walbaum, 1792) (Parés-Sierra et al. 2014). The above-mentioned studies demonstrated the potential of PBM as an alternative feed ingredient for aquaculture. However, there are concerns that substantial replacement of FM protein could ad- 
versely effect the fish flesh quality, due to lowered $(\Sigma \mathrm{n}-3$ PUFA) fatty acids content (Pigott 1989, Ahlgren et al. 1994). The fatty acid composition in the muscle of fish is directly affected by dietary fatty acid composition. It is important for the feed to contain balanced levels of polyunsaturated fatty acids and highly unsaturated fatty acids. So, a number of studies have been performed to evaluate the effects of alternative protein sources used in fish feeds as FM substitutes on fish fatty acid composition (Maina et al. 2003, Dias et al. 2005, Gümüş and Erdogan 2010, Nogueira et al. 2012, Gümüş and Aydin 2013, Parés-Sierra et al. 2014), and also the effects of different lipid sources used in fish feeds as energy sources (Stubhaug et al. 2005, Ruyter et al. 2006, Karapanagiotidis et al. 2007). Although the differences in the amounts of corn oil in the diet were slight, the high level of linoleic acid in corn oil affected the lipid metabolism and fatty acid bioconversion and or accumulation (Stubhaug et al. 2005). According to Karapanagiotidis et al. (2007), replacement of dietary fish oils by alpha-linolenic acid-rich oils decreased omega-3 fatty acids content in tilapia flesh. Ruyter et al. (2006) indicated that the percentages of 20:5n-3 and 22:6n-3 considerably lower, while those of 20:4n-6 and 20:4n-3 were higher in the phospholipids fractions of both liver and intestine of Atlantic salmon, Salmo salar Linnaeus, 1758, fed diets containing soybean oil. Some studies have reported that inclusion of increasing levels of alternative protein sources in feed for Nile tilapia (Gümüş and Erdogan 2010) or sole (Cabral et al. 2013) did not affect $\Sigma$ n-3 PUFA content in muscle due to the high retention of docosahexaenoic acid (DHA) in muscle of fish. However, the replacement of FM by PBM has a profound impact on the fatty acid composition of carp muscle with an increase in 18:1n-9 and $\Sigma$ n-6 PUFA (18:2n-6) and a decrease in $\Sigma$ n-3 PUFA (20:5n-3 and 22:6n-3) (Gümüş and Aydin 2013). While fatty acid composition of fish muscle has critical importance in human nutrition, the fish liver is a key organ that aid in the digestion of feed and plays an important role in fish digestive system. Therefore, researchers have recently stated their studies that the monitoring of this organ is important in FM replacement studies (Caballero et al. 2004, Rašković et al. 2011). Histological changes in liver and intestine of fish fed diets containing various levels of alternative protein sources have been previously demonstrated in different fish species by several authors (Merrifield et al. 2009, Nogales Mérida et al. 2010, Gai et al. 2012, Martínez-Llorens et al. 2012, Hu et al. 2013, Hlophe and Moyo 2014). Thus, the objective of this study was to investigate fatty acid composition and liver histology of Nile tilapia fry when FM protein is replaced by PBM protein as an alternative protein source.

\section{MATERIALS AND METHODS}

Rearing conditions of fish and feeding. The feeding trial was carried out at the Laboratory of the Fisheries Faculty of the Akdeniz University, Antalya, Turkey. Nile tilapia (Oreochromis niloticus) fry were purchased from the Laboratory of Fisheries Program of the Ortaca Vocational
School, University of Muğla, Turkey. Before the trial, the fish were acclimatized for 14 days. During this period, the fish were hand fed three times a day until apparent satiation using control diet (0PBM). Thereafter, 20 fish (0.879 $\pm 0.09 \mathrm{~g}$; mean weight $\pm \mathrm{SD}$ ) were randomly stocked per aquarium in triplicate groups for each treatment. Fifteen glass aquaria with $65 \mathrm{~L}$ of water were used for rearing the fish. Fish were fed by hand three times a day (at 0900, 1300 , and $1700 \mathrm{~h}$ ) with the experimental diets to apparent satiation for 12 weeks. Water temperatures, dissolved oxygen concentrations, and $\mathrm{pH}$ were maintained around $25 \pm$ $1^{\circ} \mathrm{C}, 5.1 \pm 0.3 \mathrm{mg} \cdot \mathrm{L}^{-1}$, and $8.1 \pm 0.3$, respectively. The photoperiod regime of $10 \mathrm{~h}$ light : $14 \mathrm{~h}$ dark was maintained throughout the experiment. The fish were maintained in accordance with the guidelines of the Akdeniz University of Animal Experiments Local Ethics Committee.

Experimental diets. The proximate composition of the main protein ingredients used in the diets was specified in our earlier paper (Gümüş and Aydin 2013). Five isonitrogenous (approximately 34\% crude protein), isolipidic (approximately 9\% crude lipid), and isoenergetic (approximately $15 \mathrm{MJ} \cdot \mathrm{kg}^{-1}$ digestible energy) experimental diets replacing $0 \%$ (control diet; 0PBM), 25\% (25PBM), 50\% (50PBM), 75\% (75PBM), and 100\% (100PBM) of FM protein by PBM protein were formulated (Table 1). Each of the test ingredients was thoroughly ground so as to pass through a $0.5 \mathrm{~mm}$ mesh sieve. All the ingredients for each experimental diet were thoroughly mixed, then lipid and water were added, and the ingredients were thoroughly mixed. The corn oil amount was different for each experimental diet; however, control feed only contained fish oil as well as corn oil. Diets were processed using a meat grinder with a $2 \mathrm{~mm}$ diameter pellets, dried at room temperature to a moisture content of less than $100 \mathrm{~g} \cdot \mathrm{kg}^{-1}$ diet, crumbled and sieved to appropriate size, sealed in plastic bags, and stored at $-20^{\circ} \mathrm{C}$ until used. Proximate and fatty acid composition of the experimental diets are presented in Table 2.

Sampling procedures and chemical analyses. At the end of the feeding trial, all fish were starved for $24 \mathrm{~h}$. Five fish from each aquarium, intended for histological examination and determination of fatty acid composition of the muscle, were randomly sampled after being euthanized by an overdose of clove oil (Talya Herbal Products Company, Antalya, Turkey). Proximate composition of the experimental diets were analysed according to standard procedures following Anonymous (1995). The crude protein content $(\mathrm{N} \times 6.25)$ was determined by the Kjeldahl method after acid digestion, the crude lipid content was determined following the Soxhlet method after ethylether extraction, the dry matter content-after drying at $105^{\circ} \mathrm{C}$ until constant weight remained stable, and the ash content - after $4 \mathrm{~h}$ incineration at $550^{\circ} \mathrm{C}$ in a combustion oven. Crude fibre content was determined after alkali and acid digestion and weighing of the residue ash. Nitrogen-free extract (NFE) was determined by the formula:

$$
\mathrm{NFE}=100-(\% \mathrm{Mo}+\% \mathrm{Pr}+\% \mathrm{Li}+\% \mathrm{As}+\% \mathrm{Fi})
$$

where Mo is moisture, $\mathrm{Pr}$ is protein content, Li is lipid content, As is ash, and Fi is fibre content. 
Table 1

Composition of the experimental diets for fry of Nile tilapia, Oreochromis niloticus

\begin{tabular}{|c|c|c|c|c|c|}
\hline \multirow{2}{*}{ Ingredient } & \multicolumn{5}{|c|}{ Experimental diet composition [\%] } \\
\hline & OPBM & $25 \mathrm{PBM}$ & $50 \mathrm{PBM}$ & $75 \mathrm{PBM}$ & 100PBM \\
\hline Fish meal & 42.30 & 31.50 & 20.70 & 10.30 & 0.00 \\
\hline PBM & 0.00 & 10.75 & 21.40 & 31.72 & 41.80 \\
\hline Corn gluten & 27.90 & 27.90 & 27.90 & 27.90 & 27.90 \\
\hline Soybean meal & 15.80 & 15.80 & 15.80 & 15.80 & 15.80 \\
\hline Corn oil & 2.00 & 3.20 & 2.25 & 1.30 & 0.50 \\
\hline Fish oil & 2.25 & 0.00 & 0.00 & 0.00 & 0.00 \\
\hline Cellulose & 2.15 & 2.81 & 3.48 & 4.16 & 4.75 \\
\hline Vitamin premix & 2.00 & 2.00 & 2.00 & 2.00 & 2.00 \\
\hline Mineral premix & 3.00 & 3.00 & 3.00 & 3.00 & 3.00 \\
\hline Methionine & 0.00 & 0.10 & 0.20 & 0.25 & 0.30 \\
\hline Lysine & 0.00 & 0.00 & 0.15 & 0.30 & 0.50 \\
\hline Threonine & 0.00 & 0.34 & 0.52 & 0.67 & 0.85 \\
\hline Sodium chloride $(\mathrm{NaCl})$ & 0.10 & 0.10 & 0.10 & 0.10 & 0.10 \\
\hline $\mathrm{CaHPO}_{4} 2 \mathrm{H}_{2} \mathrm{O}$ & 1.00 & 1.00 & 1.00 & 1.00 & 1.00 \\
\hline Carboxymethyl cellulose & 1.00 & 1.00 & 1.00 & 1.00 & 1.00 \\
\hline Chromium oxide $\left(\mathrm{Cr}_{2} \mathrm{O}_{3}\right)$ & 0.50 & 0.50 & 0.50 & 0.50 & 0.50 \\
\hline Total & 100 & 100 & 100 & 100 & 100 \\
\hline
\end{tabular}

$\mathrm{PBM}=$ poultry by-product meal; Diet code indicating percent of fish meal protein replacement with PBM protein $(0 \%, 25 \%, 50 \%, 75 \%$, and $100 \%$, respectively); For a more detailed description of the diets see Aydin and Gümüş (2013).

Fatty acids were determined by gas chromatography. For this purpose, total lipids were extracted by using a modified method of Bligh and Dyer (1959), and then saponified and methylated for fatty acid quantification (Morrison and Smith 1964).

Histological examination. Five fish per aquarium were randomly selected for histological study, subsequently killed by excess anaesthesia, and their livers were dissected (in total, 15 fish per treatment). The liver samples were fixed in $10 \%$ phosphate-buffered formalin ( $\mathrm{pH} 7.2$ ), dehydrated in a graded ethanol series, and embedded in paraffin following the standard histological procedures. Then the sections ( $5 \mu \mathrm{m}$ thick) were cut using a rotary microtome (RM2135 RT, Leica Instruments, Nußloch, Germany). All the obtained slices were stained in hematoxylin and eosin (H\&E), and examined under a light microscope (Olympus CX41, Japan).

Statistical analysis. Results were expressed as means \pm standard deviation throughout the text. All data were processed by one-way analysis of variance (ANOVA) using SPSS 15.0 (SPSS INC. Chicago, IL, USA). Differences among the means were compared using Duncan's multiple range tests at a $5 \%$ probability level.

\section{RESULTS}

The proximate- and fatty acid composition in main protein ingredients such as: FM, PBM, and soybean meal were specified in our earlier paper (Gümüş and Aydin 2013). In terms of the fatty acid composition of the ingredients, the saturated fatty acids (SFA) contents was higher in PBM $(39.76 \%)$ than in FM (31.86\%). Similarly, monounsaturated fatty acids (MUFA) content was higher in PBM (43.80\%) than in FM (18.85\%). On the other hand, the amount of polyunsaturated fatty acids (PUFA) $(12.39 \%)$ in PBM was distinctly lower than that of FM containing considerable amounts of PUFA (32.75\%) mainly composed of docosapentaenoic acid (22:5n-3) (11.90\%) and docosahexaenoic acid (22:6n-3) (17.53\%). The proximate- and fatty acid composition of experimental diets, containing graded levels of PBM are given in Table 2. The composition of fatty acids (SFA, MUFA, and PUFA) of the experimental diets ranged from $30.99 \%$ to $31.89 \%$, from $21.04 \%$ to $41.28 \%$, and from $16.88 \%$ to $30.10 \%$, respectively. $\Sigma$ n-3 PUFA and $\Sigma$ n-6 PUFA ranged from $1.17 \%$ to $20.00 \%$ and from $4.10 \%$ to $15.99 \%$, respectively. The fatty acid composition of fish fed the experimental diets containing different proportions of PBM are shown in Table 3. As the FM content decreased, there was no reduction of the SFA content in fish muscle. Compared with fish fed the control diet (OPBM), the fatty acid composition of fish fed the PBM diets had higher proportions of MUFA contents which was due to 18:1n-9. Nevertheless, PUFA, $\Sigma$ n-3 PUFA, and the $\Sigma$ n-3 $: \Sigma$ n-6 ratio significantly decreased $(P<0.05)$ with increasing PBM protein in diet. The different diet treatments resulted in significant differences in the $\Sigma$ n-3 PUFA contents of the Nile tilapia (Table 3). The $\Sigma$ n-3 PUFA in fish muscle were similar to the levels found in their respective diets. FM replacement with PBM increased $\Sigma$ n-6 PUFA contents of fish, mainly due to $18: 2 n-6$, which is present in high quantities in PBM. It is generally accepted that fatty acid composition of fish muscle reflects the fatty acid composition of their diets.

The histological examination of liver tissue in all treatments of this study, revealed no histological abnormalities. Histological images of the liver of fish representing different treatments are presented in Fig. 1. The livers of fish fed the experimental diets demonstrated normal-shaped hepatocytes but, a slightly low hepatic lipid accumulation was visible at all treatments. 
Table 2

The fatty acid- and proximate composition of experimental diets of fry of Nile tilapia, Oreochromis niloticus

\begin{tabular}{|c|c|c|c|c|c|c|}
\hline \multirow{2}{*}{\multicolumn{2}{|c|}{ Parameter }} & \multicolumn{5}{|c|}{ Experimental diet composition } \\
\hline & & OPBM & $25 \mathrm{PBM}$ & $50 \mathrm{PBM}$ & 75PBM & $100 \mathrm{PBM}$ \\
\hline \multicolumn{2}{|c|}{ Proximate composition } & \multicolumn{5}{|c|}{$[\%$, wet weight $]$} \\
\hline \multicolumn{2}{|l|}{ Dry matter } & $91.37 \pm 0.11$ & $91.79 \pm 0.07$ & $92.39 \pm 0.10$ & $91.54 \pm 0.05$ & $92.37 \pm 0.08$ \\
\hline \multicolumn{2}{|c|}{ Crude protein } & $34.13 \pm 0.30$ & $34.04 \pm 0.17$ & $34.06 \pm 0.20$ & $33.80 \pm 0.49$ & $33.62 \pm 0.25$ \\
\hline \multicolumn{2}{|c|}{ Crude lipid } & $8.61 \pm 0.21$ & $9.37 \pm 0.14$ & $9.12 \pm 0.10$ & $8.89 \pm 0.15$ & $8.76 \pm 0.13$ \\
\hline \multicolumn{2}{|l|}{ Crude ash } & $11.37 \pm 0.14$ & $11.42 \pm 0.85$ & $11.23 \pm 0.78$ & $11.42 \pm 0.23$ & $11.34 \pm 0.33$ \\
\hline \multicolumn{2}{|l|}{ Crude fibre } & $3.96 \pm 1.53$ & $4.36 \pm 1.45$ & $5.11 \pm 1.87$ & $6.27 \pm 0.97$ & $6.79 \pm 1.05$ \\
\hline \multicolumn{2}{|c|}{ Nitrogen-free extract } & $33.30 \pm 0.51$ & $32.60 \pm 0.41$ & $32.87 \pm 0.37$ & $31.16 \pm 0.42$ & $31.86 \pm 0.47$ \\
\hline \multicolumn{2}{|c|}{ Digestibility energy $^{1}\left[\mathrm{MJ} \cdot \mathrm{kg}^{-1}\right]$} & 15.02 & 14.97 & 14.95 & 14.92 & 14.93 \\
\hline \multicolumn{2}{|c|}{ Fatty acid ${ }^{2}$} & \multicolumn{5}{|c|}{$[\%$, of total fatty acids $]$} \\
\hline $\mathrm{C} 14: 0$ & Myristic acid & 6.44 & 5.41 & 4.26 & 2.87 & 1.34 \\
\hline $\mathrm{C} 15: 0$ & Pentadecanoic acid & 0.47 & 0.41 & 0.33 & 0.23 & 0.12 \\
\hline C16:0 & Palmitic acid & 19.12 & 20.00 & 21.16 & 23.80 & 27.25 \\
\hline C16:1 & Palmiteloic acid & 6.23 & 5.68 & 5.05 & 4.42 & 3.74 \\
\hline C17:0 & Heptadecanoic acid & 0.00 & 0.86 & 0.68 & 0.37 & 0.31 \\
\hline C18:0 & Stearic acid & 4.47 & 5.15 & 5.95 & 7.26 & 8.99 \\
\hline C18:1 & Oleic acid & 12.13 & 16.37 & 21.38 & 29.06 & 37.13 \\
\hline C18:2n-6 & Linoleic acid & 3.15 & 6.87 & 11.29 & 15.70 & 15.71 \\
\hline C18:3n-3 & $\alpha$-Linolenic acid & 0.98 & 1.08 & 1.19 & 1.13 & 0.63 \\
\hline C18:3n-6 & $\gamma$-Linolenic acid & 0.14 & 0.11 & 0.08 & 0.00 & 0.00 \\
\hline C20:0 & Arachidic acid & 0.49 & 0.42 & 0.35 & 0.27 & 0.16 \\
\hline C20:1 & Eicosenoic acid & 2.68 & 2.28 & 1.77 & 1.16 & 0.41 \\
\hline$C 20: 2 n-6$ & Eicosadienoic acid & 0.16 & 0.16 & 0.15 & 0.12 & 0.00 \\
\hline$C 20: 4 n-6$ & Arachidonic acid & 0.81 & 0.69 & 0.53 & 0.29 & 0.00 \\
\hline$C 20: 5 n-3$ & Eicosapentaenoic acid & 13.88 & 11.40 & 8.44 & 4.05 & 0.35 \\
\hline C22:6n-3 & Docosahexaenoic acid & 11.14 & 9.10 & 6.58 & 3.01 & 0.19 \\
\hline$\Sigma$ SFA & & 30.99 & 32.25 & 32.73 & 34.80 & 38.17 \\
\hline$\Sigma$ MUFA & & 21.04 & 24.33 & 28.20 & 34.64 & 41.28 \\
\hline$\Sigma \mathrm{n}-3$ PUFA & & 26.00 & 21.58 & 16.21 & 8.19 & 1.17 \\
\hline$\Sigma$ n-6 PUFA & & 4.26 & 7.83 & 12.05 & 16.11 & 15.71 \\
\hline$\Sigma$ PUFA & & 30.26 & 29.41 & 28.26 & 24.30 & 16.88 \\
\hline$\sum \mathrm{n}-3: \sum \mathrm{n}-$ & & 6.10 & 2.76 & 1.35 & 0.51 & 0.07 \\
\hline
\end{tabular}

Proximate composition values are mean $( \pm$ standard deviation) of triplicate analysis; Diet code indicating percent of fish meal protein replacement with PBM protein $(0 \%, 25 \%, 50 \%, 75 \%$, and $100 \%$, respectively); The fatty acid code indicates the degree of unsaturation (number of carbon atoms : number of double bonds);

${ }^{1}$ Digestibility energy estimated using 4.9, 9.01, and $3.49 \mathrm{kcal} \cdot \mathrm{g}^{-1}$ for protein, fat, and carbohydrate, respectively (Anonymous 1993);

${ }^{2}$ Each value is the mean $( \pm$ standard deviation) of two replicates; SFA $=$ saturated fatty acids (including 14:0, 15:0, 16:0, 17:0, 18:0, and 20:0); MUFA = monounsaturated fatty acids (including 16:1, 18:1, and 20:1); PUFA = polyunsaturated fatty acids (n-3 and $\mathrm{n}-6$ fatty acids: including 18:3n-3, 20:5n-3, 22:5n-3, 22:6n-3, 18:2n-6, 18:3n-6, C20:2n-6, and 20:4n-6).

\section{DISCUSSION}

Fatty acid analyses of the feed ingredients (Gümüş and Aydin 2013) revealed that PBM used in this study contains a higher amount of $\Sigma$ n-6 PUFA (particularly 18:2n-6), along with a lower level of $\Sigma$ n-3 PUFA (particularly 22:5n-3 and 22:6n3 ) compared with FM. Analyses of the experimental diets showed that the fatty acid composition was not similar among the diets (Table 2). Likewise, Yigit et al. (2006) showed that the replacement diets contained less $\Sigma$ n-3 HUFA than the control diet because of the lower content of lipids in the FM. It is well known that dietary fatty acid contents influences fatty acid composition in muscle of fish (Higgs et al. 2006, Bahurmiz and $\mathrm{Ng} \mathrm{2007,} \mathrm{Borquez} \mathrm{et} \mathrm{al.} \mathrm{2011).} \mathrm{The} \mathrm{results} \mathrm{of} \mathrm{the}$ presently reported study, show that replacement of FM pro- tein by PBM protein modified the fatty acid composition of fish tissue (Table 3), as reported in previous studies (Gümüş and Erdogan 2010, Gümüş and Aydin 2013, Parés-Sierra et al. 2014). Our findings disagree with other studies which demonstrated that alternative protein sources did not influence fatty acid composition of fish (Gümüş 2011, Nogueira et al. 2012). In the presently reported study, the increasing SFA content in the experimental diets was not reflected in the muscle tissue composition. But, MUFA and PUFA contents were affected by experimental diets. However, Nogueira et al. (2012) observed that SFA, $\Sigma$ n-3 PUFA and $\Sigma$ n-6 PUFA concentrations of the whole-body were not affected by blood and feather meal supplementation, whereas differences were found in total MUFA. PBM containing 20\% lipid (predomi- 
Table 3

The fatty acid composition in muscle of fry of Nile tilapia, Oreochromis niloticus fed the experimental diets

\begin{tabular}{|c|c|c|c|c|c|c|}
\hline \multirow{2}{*}{ Parameter } & & \multicolumn{5}{|c|}{ Experimental diet composition [\%, on total fatty acids] } \\
\hline & & OPBM & 25PBM & $50 \mathrm{PBM}$ & 75PBM & 100PBM \\
\hline $\mathrm{C} 14: 0$ & Myristic acid, & $4.71 \pm 0.20^{\mathrm{a}}$ & $3.72 \pm 0.27^{b}$ & $3.23 \pm 0.13^{c}$ & $2.58 \pm 0.04^{\mathrm{d}}$ & $2.32 \pm 0.17^{\mathrm{d}}$ \\
\hline C14:1 & Myristoleic acid, & $0.12 \pm 0.01$ & $0.16 \pm 0.06$ & $0.11 \pm 0.02$ & $0.30 \pm 0.28$ & $0.16 \pm 0.02$ \\
\hline $\mathrm{C} 15: 0$ & Pentadecanoic acid, & $0.48 \pm 0.03^{\mathrm{a}}$ & $0.44 \pm 0.01^{\mathrm{ab}}$ & $0.42 \pm 0.01^{\mathrm{b}}$ & $0.41 \pm 0.02^{\mathrm{b}}$ & $0.44 \pm 0.05^{\mathrm{ab}}$ \\
\hline $\mathrm{C} 16: 0$ & Palmitic acid, & $20.24 \pm 0.28^{c}$ & $21.05 \pm 0.22^{\mathrm{c}}$ & $21.01 \pm 0.21^{\mathrm{c}}$ & $23.69 \pm 0.26^{\mathrm{b}}$ & $25.80 \pm 1.43^{\mathrm{a}}$ \\
\hline C16:1 & Palmiteloic acid, & $7.11 \pm 0.01^{\mathrm{a}}$ & $6.72 \pm 0.45^{\mathrm{a}}$ & $5.97 \pm 0.18^{\mathrm{b}}$ & $5.45 \pm 0.18^{\mathrm{c}}$ & $5.94 \pm 0.20^{\mathrm{b}}$ \\
\hline $\mathrm{C} 17: 0$ & Heptadecanoic acid, & $0.57 \pm 0.01^{\mathrm{a}}$ & $0.53 \pm 0.02^{\mathrm{ab}}$ & $0.49 \pm 0.01^{\mathrm{ab}}$ & $0.38 \pm 0.11^{\mathrm{b}}$ & $0.42 \pm 0.14^{\mathrm{b}}$ \\
\hline C18:0 & Stearic acid, & $3.91 \pm 0.03$ & $4.77 \pm 0.24$ & $5.35 \pm 0.11$ & $5.26 \pm 1.79$ & $2.50 \pm 4.03$ \\
\hline C18:1n-9 & Oleic acid, & $17.71 \pm 1.15^{\mathrm{e}}$ & $23.35 \pm 0.95^{\mathrm{d}}$ & $26.08 \pm 0.18^{\mathrm{c}}$ & $31.31 \pm 0.27^{\mathrm{b}}$ & $33.92 \pm 1.23^{\mathrm{a}}$ \\
\hline C18:2n-6 & Linoleic acid, & $3.86 \pm 0.15^{\mathrm{d}}$ & $6.90 \pm 0.81^{\mathrm{c}}$ & $10.14 \pm 0.24^{\mathrm{b}}$ & $11.86 \pm 0.54^{\mathrm{a}}$ & $7.11 \pm 0.38^{c}$ \\
\hline C18:3n-3 & $\alpha$-Linolenic acid, & $0.72 \pm 0.02^{\mathrm{ab}}$ & $0.71 \pm 0.04^{\mathrm{ab}}$ & $0.85 \pm 0.02^{\mathrm{a}}$ & $0.66 \pm 0.05^{b}$ & $0.23 \pm 0.16^{c}$ \\
\hline C18:3n-6 & $\gamma$-Linolenic acid, & $0.13 \pm 0.01^{\mathrm{c}}$ & $0.21 \pm 0.01^{\mathrm{c}}$ & $0.20 \pm 0.01^{\mathrm{c}}$ & $0.41 \pm 0.03^{b}$ & $0.76 \pm 0.15^{\mathrm{a}}$ \\
\hline $\mathrm{C} 20: 0$ & Arachidic acid, & $0.22 \pm 0.03^{b}$ & $0.23 \pm 0.02^{\mathrm{ab}}$ & $0.23 \pm 0.01^{\mathrm{ab}}$ & $0.25 \pm 0.01^{\mathrm{a}}$ & $0.24 \pm 0.01^{\mathrm{ab}}$ \\
\hline $\mathrm{C} 20: 1$ & Eicosenoic acid, & $2.12 \pm 0.06^{\mathrm{a}}$ & $1.86 \pm 0.09^{\mathrm{b}}$ & $1.70 \pm 0.03^{\mathrm{c}}$ & $1.48 \pm 0.06^{\mathrm{d}}$ & $1.50 \pm 0.08^{\mathrm{d}}$ \\
\hline$C 20: 2 n-6$ & Eicosadienoic acid, & $0.22 \pm 0.02^{\mathrm{c}}$ & $0.27 \pm 0.02^{\mathrm{bc}}$ & $0.33 \pm 0.05^{b}$ & $0.45 \pm 0.02^{\mathrm{a}}$ & $0.26 \pm 0.09^{\mathrm{bc}}$ \\
\hline$C 20: 3 n-3$ & Eicosatrienoic acid, & $0.14 \pm 0.01^{\mathrm{d}}$ & $0.21 \pm 0.04^{c}$ & $0.26 \pm 0.02^{\mathrm{c}}$ & $0.42 \pm 0.01^{\mathrm{b}}$ & $0.52 \pm 0.08^{\mathrm{a}}$ \\
\hline$C 20: 4 n-6$ & Arachidonic acid, & $0.34 \pm 0.03^{b}$ & $0.53 \pm 0.07^{\mathrm{ab}}$ & $0.55 \pm 0.02^{\mathrm{ab}}$ & $0.58 \pm 0.11^{\mathrm{ab}}$ & $0.69 \pm 0.29^{\mathrm{a}}$ \\
\hline$C 20: 5 n-3$ & Eicosapentaenoic acid, & $4.40 \pm 0.01^{\mathrm{a}}$ & $2.45 \pm 0.31^{\mathrm{b}}$ & $1.96 \pm 0.08^{\mathrm{c}}$ & $0.53 \pm 0.03^{\mathrm{d}}$ & $0.37 \pm 0.09^{\mathrm{d}}$ \\
\hline $\mathrm{C} 21: 0$ & Heneicosanoic acid, & $0.28 \pm 0.06^{\mathrm{a}}$ & $0.24 \pm 0.03^{\mathrm{a}}$ & $0.23 \pm 0.02^{\mathrm{ab}}$ & $0.17 \pm 0.02^{\mathrm{b}}$ & $0.10 \pm 0.03^{\mathrm{c}}$ \\
\hline C22:1n-9 & Erucic acid, & $0.21 \pm 0.08^{\mathrm{a}}$ & $0.18 \pm 0.02^{\mathrm{ab}}$ & $0.16 \pm 0.01^{\mathrm{ab}}$ & $0.11 \pm 0.01^{\mathrm{ab}}$ & $0.11 \pm 0.02^{\mathrm{b}}$ \\
\hline$C 22: 2 n-6$ & Docosadienoic acid, & $1.11 \pm 0.04^{\mathrm{ab}}$ & $1.22 \pm 0.15^{\mathrm{a}}$ & $0.97 \pm 0.03^{\mathrm{b}}$ & $0.45 \pm 0.04^{\mathrm{c}}$ & $0.12 \pm 0.13^{\mathrm{d}}$ \\
\hline$C 22: 6 n-3$ & Docosahexaenoic acid, & $12.15 \pm 0.10^{\mathrm{a}}$ & $8.91 \pm 0.93^{\mathrm{b}}$ & $6.93 \pm 0.26^{\mathrm{c}}$ & $3.19 \pm 0.47^{\mathrm{d}}$ & $1.21 \pm 0.90^{\mathrm{e}}$ \\
\hline$\Sigma \mathrm{SFA}^{1}$ & & $30.42 \pm 0.48$ & $30.98 \pm 0.15$ & $30.96 \pm 0.33$ & $32.75 \pm 1.80$ & $31.82 \pm 3.80$ \\
\hline$\Sigma$ MUFA $^{2}$ & & $27.27 \pm 1.02^{\mathrm{e}}$ & $32.27 \pm 0.88^{\mathrm{d}}$ & $34.02 \pm 0.17^{\mathrm{c}}$ & $38.65 \pm 0.40^{\mathrm{b}}$ & $41.63 \pm 1.38^{\mathrm{a}}$ \\
\hline$\Sigma$ n-3 PUFA ${ }^{3}$ & & $17.41 \pm 0.09^{\mathrm{a}}$ & $12.29 \pm 1.23^{\mathrm{b}}$ & $10.00 \pm 0.36^{\mathrm{c}}$ & $4.80 \pm 0.46^{\mathrm{d}}$ & $2.33 \pm 0.04^{\mathrm{e}}$ \\
\hline$\sum$ n-6 PUFA ${ }^{4}$ & & $5.66 \pm 0.16^{\mathrm{c}}$ & $9.13 \pm 0.86^{\mathrm{b}}$ & $12.19 \pm 0.32^{\mathrm{a}}$ & $13.75 \pm 0.40^{\mathrm{a}}$ & $8.94 \pm 1.74^{\mathrm{b}}$ \\
\hline$\Sigma \mathrm{PUFA}^{5}$ & & $23.07 \pm 0.25^{\mathrm{a}}$ & $21.42 \pm 0.95^{\mathrm{a}}$ & $22.19 \pm 0.68^{\mathrm{a}}$ & $18.55 \pm 0.60^{\mathrm{b}}$ & $11.27 \pm 2.78^{c}$ \\
\hline$\sum \mathrm{n}-3: \sum \mathrm{n}-6 \mathrm{r}$ & & $3.07 \pm 0.07^{\mathrm{a}}$ & $1.35 \pm 0.23^{\mathrm{b}}$ & $0.82 \pm 0.01^{\mathrm{c}}$ & $0.35 \pm 0.03^{\mathrm{d}}$ & $0.26 \pm 0.06^{\mathrm{d}}$ \\
\hline
\end{tabular}

Values in the same row with different superscripts are significantly different $(P<0.05)$; Fatty acids composition values are mean $( \pm \mathrm{SD})$ of two analyses.

${ }^{1}$ Total saturated fatty acids included C14:0, C15:0, C16:0, C17:0, C18:0, and C20:0;

${ }^{2}$ Total MUFA (Monounsaturated fatty acids) included C14:1, C16:1, C18:1n-9, C20:1n-9, and C24:1;

${ }^{3}$ Total n-3 PUFA (Polyunsaturated fatty acids) included C18:3n-3, C20:5n-3, C22:5n-3, and C22:6n-3.

${ }^{4}$ Total n-6 PUFA (Polyunsaturated fatty acids) included C18:2n-6, C18:3n-6, C20:2n-6, and C22:2n-6;

${ }^{5}$ Total PUFA (Polyunsaturated fatty acids) included C18:2n-6, C18:3n-3, C18:3n-6, C20:2n-6, C20:3n-3, C20:5n-3, C22:2n-6, and C22:6n-3.

nantly from $\mathrm{C} 16: 0$ and $\mathrm{C} 18: 1 \mathrm{n}-9$ fatty acids) was the primary protein source and no FM was used in 100PBM diet. Fatty acid analyses revealed that clear differences in fatty acids in muscle tissue from diet 100PBM, where levels of 16:0, 18:1n9, and 18:3n-6 were significantly higher, while 20:5n-3 and 22:6n-3 were lower. Similarly to these results, Parés-Sierra et al. (2014) showed that rainbow trout feeding with PBM, resulted in lower 20:5n-3 and 22:6n-3 contents. The amount of $\Sigma$ n-3 PUFA in the muscle of fish fed the 100PBM diet was $2.3 \%$, while in control was $17.4 \%$. FM replacement with different proportions of PBM caused a decline of $\Sigma$ n-3 PUFA levels because of low levels of $\Sigma$ n-3 PUFA levels in diets. Similar results were reported in the mirror carp (Cyprinus carpio) fed diets with graded levels of sand smelt meal and PBM (Gümüş 2011, Gümüş and Aydin 2013). But, Gümüş and Erdogan (2010) reported that the level of $\Sigma$ n-3 PUFA did not affect significantly fatty acid composition of the fry of Nile tilapia (Oreochromis niloticus) muscle fed diets having tuna liver meal inclusions at different proportions. On the other hand, there was a high increase in the levels of MUFA (particularly C18:1n-9) and n-6 PUFA (particularly 18:2n-6) in fish fed PBM based diets. This is in agreement with other studies showing that fatty acid compositions of fish are affected by dietary protein sources (Gümüş and Aydin 2013, Parés-Sierra et al. 2014). Tilapia are omnivorous fish, so they do not require high inclusion rate of FM, and do need greater amounts of $\Sigma$ n-6 PUFA than $\Sigma$ n-3 PUFA in their diets (Takeuchi et al. 2002, Gümüş and Erdogan 2010).

Evaluation of histological structure of fish liver is important to assessing the effects of various nutrient feedstuffs that use raw materials in diet (Caballero et al. 2004, Rašković et al. 2011, Marković et al. 2012, Hu et al. 2013). In the presently reported study, the liver of fish fed the experimental diets demonstrated normal-shaped hepatocytes but, lower lipid ac- 

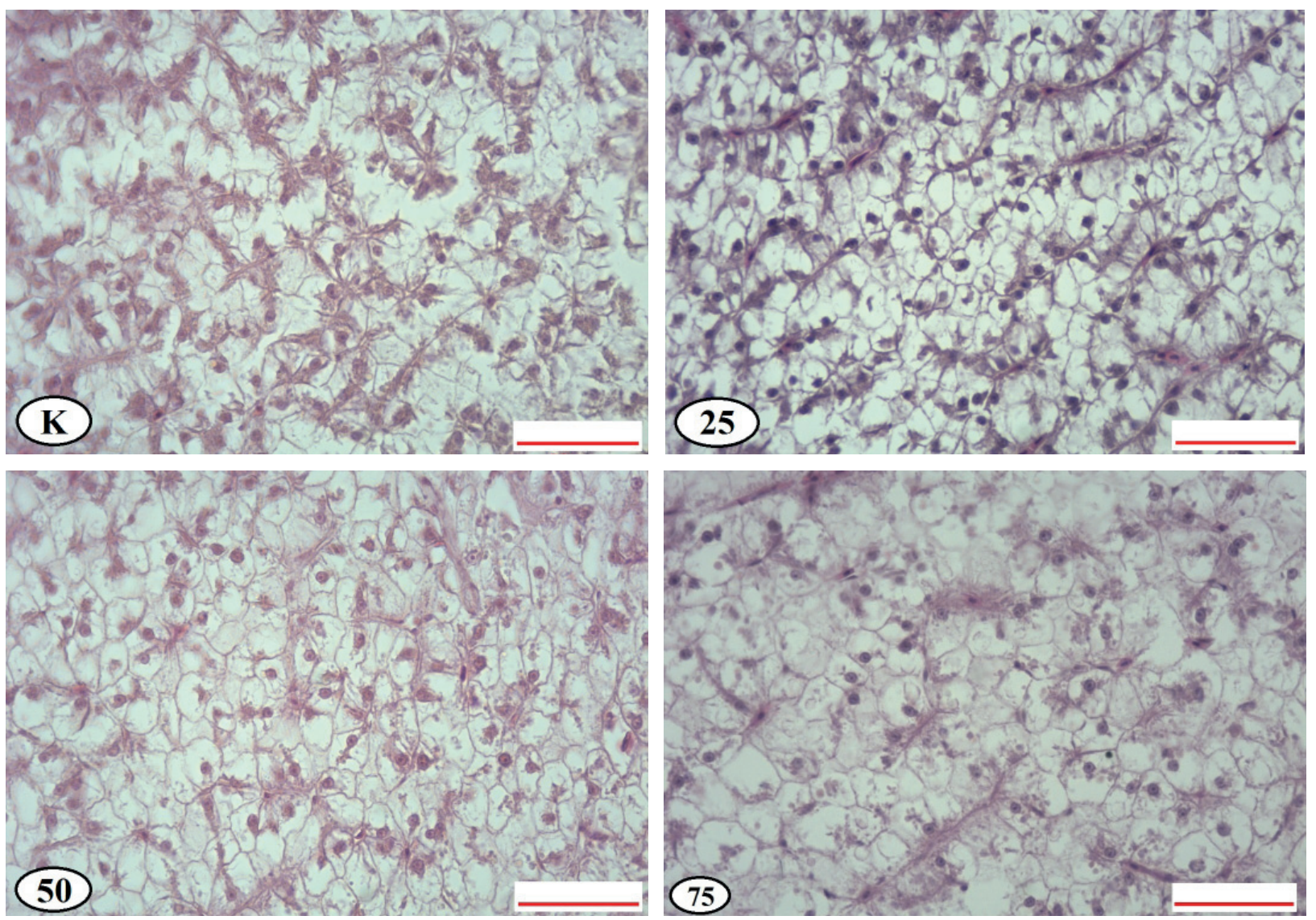

Fig. 1. Cross sections of the liver of fry of Nile tilapia, Oreochromis niloticus, including $(\mathrm{K})$ fed diet OPBM, (25) fed diet 25PBM, (50) fed diet 50PBM, (75) fed diet 75PBM, or (100) fed diet 100PBM for 12 weeks; Scale bars $=50 \mu \mathrm{m}$

cumulation in liver of fish fed diets containing graded levels of PBM. Similarly, Glencross et al. (2004) reported that small lipid droplet formation in the liver of rainbow trout was observed, which may in part be related to the poorer energy retention of a diet that included high levels of yellow lupin kernel meal. Likewise, the hepatocyte morphology of sharpsnout sea bream, Diplodus puntazzo (Walbaum, 1792), appeared to not be altered by plant protein substitution (Nogales Mérida et al. 2010). In contrast to our findings, Hlophe and Moyo (2014) reported that liver histology indicated an increase in hepatocyte degradation with increasing levels of Kikuyu grass meal and moringa leaves meal. Similarly, $\mathrm{Hu}$ et al. (2013) reported that high substitution of fish meal by animal protein blend (up to $60 \%$ and $80 \%$ ) appeared to enlarge the

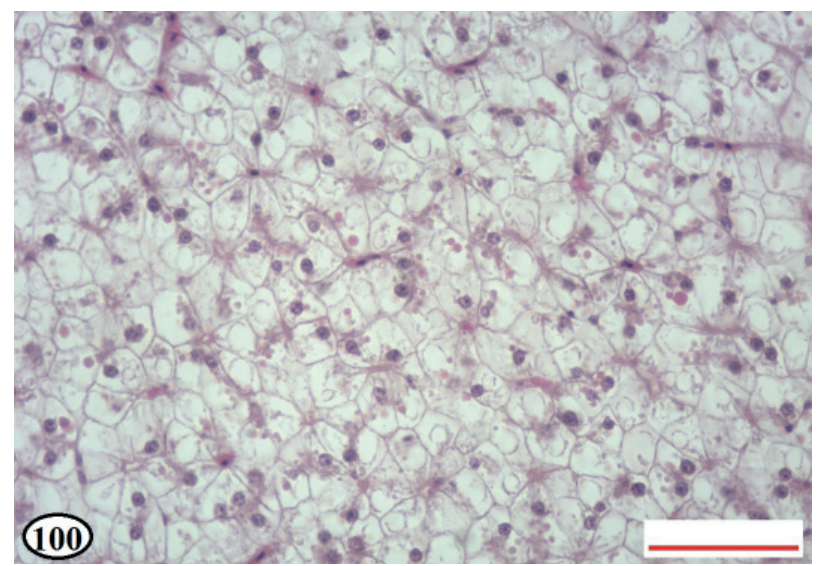
hepatocytes and induce apparent hepatic steatosis.

In conclusion, the concentrations of $\Sigma$ n-3 HUFA declined in the muscles of fish fed 75PBM and 100PBM diets. Although we found the significant decrease of $\Sigma$ n-3 PUFA and the $\Sigma$ n-3 : $\Sigma$ n- 6 ratio in groups of 50PBM, $50 \%$ fishmeal protein could be replaced by PBM protein. The results also show that using poultry by-product meal in the diets for Nile tilapia do not significantly affect liver histology indicating that these alternative proteins are usable in levels up to $500 \mathrm{~g} \cdot \mathrm{kg}^{-1}$ in diets for Nile tilapia. The current study was carried out for a short period of time, and it also should be studied the nutritional quality of PBM, in which supplemented of lysine, methionine, and threonine amino acids, as a substitute for FM in diets for marketable fish under field conditions. 


\section{ACKNOWLEDGEMENTS}

This study was financially supported by the Scientific Research Projects Coordination Unit of the Akdeniz University (grant No. 2009.02.0121.007). The results presented in this paper were taken from the M. Phil. thesis of the first author. We sincerely thank Yusuf Aktop and Abdulkerim Aksoy for their assistance in the histological examination of the liver samples.

\section{REFERENCES}

AhIgren G., Blomqvist P., Boberg M., Gustafsson I.-B. 1994. Fatty acid content of the dorsal muscle-An indicator of fat quality in freshwater fish. Journal of Fish Biology 45 (1): 131-157.

DOI: $10.1111 /$ j.1095-8649.1994.tb01292.x

Anonymous 1993. Nutrient requirements of fish. National Academy Press, Washington, DC, USA.

Anonymous 1995. Official methods of analysis. 16th edn. Association of Official Analytical Chemists International, Arlington, Virginia, USA.

Aydin B., Gümüş E. 2013. Replacement of fishmeal by poultry by-product meal, supplemented with lysine, methionine, and threonine, in diets for fry of Nile tilapia (Oreochromis niloticus). Israeli Journal of Aquaculture-Bamidgeh 65: IJA_65.2013.885.

Bahurmiz O.M., Ng W.-K. 2007. Effects of dietary palm oil source on growth, tissue fatty acid composition and nutrient digestibility of red hybrid tilapia, Oreochromis sp., raised from stocking to marketable size. Aquaculture 262 (2-4): 382-392.

DOI: $10.1016 /$ j.aquaculture.2006.11.023

Bligh E.G., Dyer W.J. 1959. A rapid method of total lipid extraction and purification. Canadian Journal of Biochemistry and Physiology 37 (8): 911-917. DOI: 10.1139/059-099

Borquez A., Serrano E., Dantagnan P., Carrasco J., Hernandez A. 2011. Feeding high inclusion of whole grain white lupin (Lupinus albus) to rainbow trout (Oncorhynchus mykiss): Effects on growth, nutrient digestibility, liver and intestine histology and muscle fatty acid composition. Aquaculture Research 42 (8): 1067-1078.

DOI: $10.1111 / \mathrm{j} .1365-2109.2010 .02690 . x$

Caballero M.J., Izquierdo M.S., Kjørsvik E., Fernández A.J., Rosenlund G. 2004. Histological alterations in the liver of sea bream, Sparus aurata L., caused by short- or long-term feeding with vegetable oils. Recovery of normal morphology after feeding fish oil as the sole lipid source. Journal of Fish Diseases 27 (9): 531-541.

DOI: $10.1111 / \mathrm{j} .1365-2761.2004 .00572 . x$

Cabral E.M., Fernandes T.J.R., Campos S.D., Castro-Cunha M., Oliveira M.B.P.P., Cunha L.M., Valente L.M.P. 2013. Replacement of fish meal by plant protein sources up to $75 \%$ induces good growth performance without affecting flesh quality in ongrowing Senegalese sole. Aquaculture 380-383: 130-138. DOI: $10.1016 /$ j.aquaculture.2012.12.006
Dias J., Alvarez M.J., Arzel J., Corraze G., Diez A., Bautista J.M., Kaushik S.J. 2005. Dietary protein source affects lipid metabolism in the European seabass (Dicentrarchus labrax). Comparative Biochemistry and Physiology Part A: Molecular and Integrative Physiology 142 (1): 19-31.

DOI: $10.1016 /$ j.cbpb.2005.07.005

Emre Y., Sevgili H., Diler I. 2003. Replacing fish meal with poultry by-product meal in practical diets for mirror carp (Cyprinus carpio) fingerlings. Turkish Journal of Fisheries and Aquatic Sciences 3 (2): 81-85.

Gai F., Gasco L., Daprà F., Palmegiano G.B., Sicuro B. 2012. Enzymatic and histological evaluations of gut and liver in rainbow trout, Oncorhynchus mykiss, fed with rice protein concentrate-based diets. Journal of the World Aquaculture Society 43 (2): 218-229. DOI: $10.1111 / \mathrm{j} .1749-7345.2012 .00557 . \mathrm{x}$

Glencross B., Evans D., Hawkins W., Jones B. 2004. Evaluation of dietary inclusion of yellow lupin (Lupinus luteus) kernel meal on the growth, feed utilization and tissue histology of rainbow trout (Oncorhynchus mykiss). Aquaculture 235 (1-4): 411-422.

DOI: $10.1016 /$ j.aquaculture.2003.09.022

Gümüş E. 2011. Fatty acid composition of fry mirror carp (Cyprinus carpio) fed graded levels of sand smelt (Atherina boyeri) meal. Asian-Australasian Journal of Animal Sciences 24 (2): 264-271.

DOI: 10.5713 /ajas.2011.10223

Gümüş E., Aydin B. 2013. Effect of poultry by-product meal on growth performance and fatty acid composition of carp (Cyprinus carpio) fry. Turkish Journal of Fisheries and Aquatic Sciences 13 (5): 827-834.

DOI: $10.4194 / 1303-2712-v 13$ 5_06

Gümüş E., Erdogan F. 2010. Effects of partial substitution of fish meal with tuna liver meal on the fatty acid profile of Nile tilapia fry, Oreochromis niloticus. Kafkas Üniversitesi Veteriner Fakültesi Dergisi 16 (Suppl. B): S283-S290.

DOI: $10.9775 / \mathrm{kvfd} .2010 .2216$

Hernández C., Olvera-Novoa M.A., Hardy R.W., Hermosillo A., Reyes C., González B. 2010. Complete replacement of fish meal by porcine and poultry by-product meals in practical diets for fingerling Nile tilapia Oreochromis niloticus: Digestibility and growth performance. Aquaculture Nutrition 16 (1): 44-53. DOI: $10.1111 /$ j.1365-2095.2008.00639.x

Hernández C., Osuna-Osuna L., Benitez-Hernandez A., Sanchez-Gutierrez Y., González-Rodríguez B., Dominguez-Jimenez P. 2014. Replacement of fish meal by poultry by-product meal, food grade, in diets for juvenile spotted rose snapper (Lutjanus guttatus). Latin American Journal of Aquatic Research 42 (1): 111-120. DOI: 103856/vol42-issue1-fulltext-8

Higgs D.A., Balfry S.K., Oakes J.D., Rowshandeli M., Skura B.J., Deacon G. 2006. Efficacy of an equal blend of canola oil and poultry fat as an alternate dietary lipid source for Atlantic salmon (Salmo salar L.) in sea water. I: Effects on growth performance, and 
whole body and fillet proximate and lipid composition. Aquaculture Research 37 (2): 180-191.

DOI: $10.1111 / \mathrm{j} .1365-2109.2005 .01420 . x$

Hlophe S.N., Moyo N.A.G. 2014. Replacing fishmeal with Kikuyu grass and moringa leaves: Effects on growth, protein digestibility, histological and haematological parameters in Clarias gariepinus. Turkish Journal of Fisheries and Aquatic Sciences 14 (3): 795-806.

DOI: 10.4194/1303-2712-v14_3_22

Hu L., Yun B., Xue M., Wang J., Wu X., Zheng Y., Han F. 2013. Effects of fish meal quality and fish meal substitution by animal protein blend on growth performance, flesh quality and liver histology of Japanese seabass (Lateolabrax japonicus). Aquaculture 372-375: 52-61.

DOI: 10.1016/j.aquaculture.2012.10.025

Ismail S., Kamarudin M.S., Ramezani-Fard E. 2012. Performance of commercial poultry offal meal as fishmeal replacement in the diet of juvenile Malaysian mahseer, Tor tambroides. Asian Journal of Animal and Veterinary Advances 8 (2): 284-292.

DOI: 10.3923 /ajava.2013.284.292

Karapanagiotidis I.T., Bell M.V., Little D.C., Yakupitiyage A. 2007. Replacement of dietary fish oils by alpha-linolenic acid-rich oils lowers omega 3 content in tilapia flesh. Lipids 42 (6): 547-559.

DOI: $10.1007 / \mathrm{s} 11745-007-3057-1$

Maina J.G., Beames R.M., Higgs D., Mbugua P.N., Iwama G., Kisia S.M. 2003. Partial replacement of fishmeal with sunflower cake and corn oil in diets for tilapia Oreochromis niloticus (Linn): Effect on whole body fatty acids. Aquaculture Research 34 (8): 601608 .

DOI: 10.1046/j.1365-2109.2003.00848.x

Marković Z., Poleksić V., Lakić N., Živić I., Dulić Z., Stanković M., Spasić M., Rašković B., Sørensen M. 2012. Evaluation of growth and histology of liver and intestine in juvenile carp (Cyprinus carpio, L.) fed extruded diets with or without fish meal. Turkish Journal of Fisheries and Aquatic Sciences 12 (2): 301-308. DOI: 10.4194/1303-2712-v12_2_15

Martínez-Llorens S., Baeza-Ariño R., Nogales-Mérida S., Jover-Cerdá M., Tomás-Vidal A. 2012. Carob seed germ meal as a partial substitute in gilthead sea bream (Sparus aurata) diets: Amino acid retention, digestibility, gut and liver histology. Aquaculture 338341: 124-133.

DOI: $10.1016 /$ j.aquaculture.2012.01.029

Merrifield D.L., Dimitroglou A., Bradley G., Baker R.T.M., Davies S.J. 2009. Soybean meal alters autochthonous microbial populations, microvilli morphology and compromises intestinal enterocyte integrity of rainbow trout, Oncorhynchus mykiss (Walbaum). Journal of Fish Diseases 32 (9): 755-766.

DOI: $10.1111 / \mathrm{j} .1365-2761.2009 .01052 . \mathrm{x}$
Morrison W.R., Smith L.M. 1964. Preparation of fatty acid methyl esters and dimethylacetals from lipids with boron fluoride-methanol. The Journal of Lipid Research 5: 600-608.

Nogales Mérida S., Tomás-Vidal A., Martínez-Llorens S., Cerdá M.J. 2010. Sunflower meal as a partial substitute in juvenile sharpsnout sea bream (Diplodus puntazzo) diets: Amino acid retention, gut and liver histology. Aquaculture 298 (3-4): 275-281.

DOI: $10.1016 /$ j.aquaculture.2009.10.025

Nogueira N., Cordeiro N., Andrade C., Aires T. 2012. Inclusion of low levels of blood and feathermeal in practical diets for gilthead seabream (Sparus aurata). Turkish Journal of Fisheries and Aquatic Sciences 12 (3): $641-650$.

DOI: 10.4194/1303-2712-v12_3_12

Parés-Sierra G., Durazo E., Ponce M.A., Badillo D., Correa-Reyes G., Viana M.T. 2014. Partial to total replacement of fishmeal by poultry by-product meal in diets for juvenile rainbow trout (Oncorhynchus mykiss) and their effect on fatty acids from muscle tissue and the time required to retrieve the effect. Aquaculture Research 45 (9): 1459-1469.

DOI: 10.1111 /are.12092

Pigott G.M. 1989. The need to improve omega-3 content of cultured fish. World Aquaculture 20: 63-68.

Rašković B.S., Stanković M.B., Marković Z.Z., Poleksić V.D. 2011. Histological methods in the assessment of different feed effects on liver and intestine of fish. Journal of Agricultural Sciences 56 (1): $87-100$.

DOI: $10.2298 /$ jas $1101087 \mathrm{r}$

Ruyter B., Moya-Falcón C., Rosenlund G., Vegusdal A. 2006. Fat content and morphology of liver and intestine of Atlantic salmon (Salmo salar): Effects of temperature and dietary soybean oil. Aquaculture $\mathbf{2 5 2}$ (2-4): 441-452.

DOI: $10.1016 /$ j.aquaculture.2005.07.014

Stubhaug I., Froyland L., Torstensen B.E. 2005. $\beta$-oxidation capacity of red and white muscle and liver in Atlantic salmon (Salmo salar L.) - Effects of increasing dietary rapeseed oil and olive oil to replace capelin oil. Lipids 40 (1): 39-47.

DOI: $10.1007 / \mathrm{s} 11745-005-1358-4$

Takeuchi T., Satoh S., Kiron V. 2002. Common carp, Cyprinus carpio. Pp. 245-261. In: Webster C.D., Lim C.E. (eds.) Nutrient requirements and feeding of finfish for aquaculture. CABI Publishing, Oxon.

Turker A., Yigit M., Ergun S., Karaali B., Erteken A. 2005. Potential of poultry by-product meal as a substitute for fishmeal in diets for black sea turbot Scophthalmus maeoticus: growth and nutrient utilization in winter. The Israeli Journal of Aquaculture-Bamidgeh 57 (1): 49-61.

Watanabe T. 2002. Strategies for further development of aquatic feeds. Fisheries Science 68 (2): 242-252. DOI: $10.1046 /$ j.1444-2906.2002.00418.x 
Yang Y., Xie S., Cui Y., Zhu X., Lei W., Yang Y. 2006. Yigit M., Erdem M., Koshio S., Ergun S., Turker A., Partial and total replacement of fishmeal with poultry by-product meal in diets for gibel carp, Carassius auratus gibelio Bloch. Aquaculture Research 37 (1): 40-48.

DOI: $10.1111 / \mathrm{j} .1365-2109.2005 .01391 . x$

Karaali B. 2006. Substituting fish meal with poultry by-product meal in diets for Black Sea turbot Psetta maeotica. Aquaculture Nutrition 12 (5): 340-347.

DOI: $10.1111 /$ j.1365-2095.2006.00409.x

Received: 26 January 2015

Accepted: 15 October 2015

Published electronically: 31 December 2015 